\title{
PENCEGAHAN PENYEBARAN TUBERKULOSIS PARU DENGAN (BEEB) BATUK EFEKTIF DAN ETIKA BATUK DI RW. VI SAMBIKEREP SURABAYA
}

\author{
Siti Nur Hasina ${ }^{1}$ \\ ${ }^{1)}$ S1 Keperawatan, Fakultas Keperawatan dan Kebidanan, Universitas Nahdlatul Ulama Surabaya \\ e-mail: sitinurhasina@unusa.ac.id
}

\begin{abstract}
Abstrak
Kasus tuberkulosis paru merupakan penyakit menular yang disebabkan mycobacterium tuberculosis dan menjadi permasalahan yang serius di Indonesia. Penderita tuberkulosis paru menyebarkan kuman ke udara dalam bentuk droplet (percikan dahak). Droplet yang mengandung kuman dapat bertahan di udara pada suhu kamar selama beberapa jam. Infeksi terjadi apabila seseorang menghirup udara yang mengandung percikan dahak infeksius tersebut. RW.VI Sambikerep merupakan suatu tempat yang padat penduduk dan terdapat perumahan warga yang berdempetan dan kurangnya ventilasi sehingga resiko penyebaran bakteri tuberkulosis yang tinggi. Sehingga pengabdian masyarakat ini bertujuan untuk menambah pengetahuan masyarakat tentang pentingnya pencegahan penyebaran tuberkulosis paru dengan BEEB dan merubah perilaku hidup sehat dan bersih agar terhindar dari penyakit Tuberkulosis. Metode dalam pengabdian masyarakat ini berupa penyuluhan dan demostrasi dengan media leaflet dan video yang disebarkan melalui media sosial warga. Pengabdian masyarakat ini dilakukan selama 1 bulan (Maret-April 2020). Kegiatan pengabdian dan masyarakat ini didapatkan peningkatan pengetahuan warga sebelum dilakukan kegiatan hasil pre test responden berpengetahuan baik sebesar 3(3,7\%) dan setelah diberikan penyuluhan dan demonstrasi responden berpengetahuan baik menjadi 74(90,2\%). Dengan adanya program pengabdian masyarakat ini, masyarakat dapat menerapkan batuk efektif dan etika batuk dalam mencegah penyebaran Tuberkulosis paru secara mandiri dan mempertahankannya untuk hidup lebih bersih dan sehat agar terhindar dari penyakit menular lainnya.
\end{abstract}

Kata Kunci: Tuberkulosis Paru (TBC), Batuk Efektif, Etika Batuk

\begin{abstract}
Pulmonary tuberculosis is a contagious disease caused by mycobacterium tuberculosis and is a serious problem in Indonesia. Patients with pulmonary tuberculosis spread germs into the air in the form of droplets (sputum sparks). Droplets containing germs can remain in the air at room temperature for several hours. Infection occurs when a person inhales the air that contains these infectious sputum sparks. RW.VI Sambikerep is a densely populated place and there are houses close to each other and lack of ventilation so the risk of spreading tuberculosis bacteria is high. So that this community service aims to increase public knowledge about the importance of preventing the spread of pulmonary tuberculosis with BEEB and changing healthy and clean living habits in order to avoid tuberculosis. This method of community service is in the form of counseling and demonstrations using leaflets and videos that are distributed through social media. This community service is carried out for 1 month (March-April 2020). This community and service activity resulted in an increase in people's knowledge before the pre-test results of the respondents with good knowledge were 3 (3.7\%) and after being given counseling and demonstrations, respondents with good knowledge were 74 (90.2\%). With this community service program, the community can implement effective coughing and cough etiquette in preventing the spread of pulmonary tuberculosis independently and maintaining it for a cleaner and healthier life to avoid other infectious diseases.
\end{abstract}

Keywords: Pulmonary Tuberculosis (TBC), Effective Cough, Cough Ethics 


\section{PENDAHULUAN}

Penyakit Tuberculosis (TB) sampai saat ini merupakan masalah kesehatan masyarakat di dunia terutama di Indonesia. TB paru menduduki peringkat ke 2 sebagai penyebab utama kematian akibat penyakit menular setelah Human Immuno deficiency Virus (HIV) (WHO, 2015). Penyakit Tuberkulosis paru mudah menyebar di udara ketika orang-orang yang sakit dengan Tuberkulosis paru melepaskan bakteri melalui mekanisme batuk sehingga orang di sekitar pasien dapat dengan mudah terinfeksi (WHO, 2017). Penyebaran bakteri ini melalui percikan dahak atau droplet nuclei yang dilepaskan oleh penderita TBC melalui batuk, bersin atau berbicara secara berhadapan langsung.

Secara global pada tahun 2016 terdapat 10,4 juta kasus insiden Tuberculosis paru yang setara dengan 120 kasus per 100.000 penduduk. insiden kasus tertinggi yaitu India, Indonesia, China, Philipina dan Pakistan. Jumlah kasus baru TB di Indonesia sebanyak 420.994 kasus pada tahun 2017 (Kemenkes RI , 2018). Berdasarkan laporan Dinas Kesehatan Provinsi Jawa Timur, penderita TB yang diobati di Jawa Timur sebanyak 40.185 orang dan jumlah penderita TB paru BTA positif sebanyak 21.475 orang. Hal ini menjadikan Provinsi Jawa Timur menempati urutan kedua dengan setelah Jawa Barat di Indonesia (Dinkes Jatim 2016). Di Jawa Timur Kota terbanyak dengan jumlah kasus TB dengan BTA posistif yaitu Surabaya sebanyak 2330 orang. Kasus baru pada tahun 2016 sebanyak 2.382 orang dengan angka kesembuhan TB dengan BTA positif sebesar 74,12\%. Selama pengobatan pada tahun 2015 terdapat kasus kematian sebanyak 117 meningkat pada tahun 2016 sebanyak 188 orang (Dinkes Kota Surabaya, 2016 dalam Nurdiana, dkk, 2018).

Derajat kesehatan dipengaruhi oleh beberapa faktor yaitu lingkungan, perilaku, pelayanan kesehatan dan keturunan. Faktor paling besar yang mempengaruhi derajat kesehatan adalah faktor lingkungan dan perilaku masyarakat sendiri yang dapat merugikan kesehatan. Penyakit Tuberkulosis merupakan penyakit berbasis lingkungan. Faktor risiko penularan Tuberkulosis adalah faktor lingkungan dan faktor perilaku, faktor lingkungan meliputi ventilasi, kepadatan hunian, suhu, pencahayaan dan kelembaban. Sedangkan faktor perilaku meliputi kebiasaan merokok, meludah atau membuang dahak di sembarang tempat, batuk atau bersin tidak menutup mulut dan kebiasaan tidak membuka jendela (Achmadi, 2005)

Pencahayaan yang kurang akan menyebabkan kelembaban yang tinggi di dalam rumah dan sangat berpotensi sebagai tempat berkembang biaknya kuman TBC. Sinar matahari dapat dimanfaatkan untuk pencegahan penyakit tuberkulosis paru, dengan mengusahakan masuknya sinar matahari pagi ke dalam rumah. Cahaya matahari yang masuk ke dalam rumah melalui jendela atau genteng kaca diutamakan sinar matahari pagi mengandung sinar ultraviolet yang dapat mematikan kuman (Fatimah, 2008). Di RW. VI Sambikerep merupakan perumahan yang padat penduduk dan kurangnya ventilasi serta cahaya matahari yang masuk sehingga resiko tinggi penyebaran Tuberkulosis yang tinggi.

Penyakit Tuberkulosis paru adalah penyakit yang disebabkan oleh bakteri Mycobacterium tuberculosis yang mana menyerang saluran pernafasan bagian bawah dengan tidak ditemukan gejala atau keluhan sampai timbul gejala seperti batuk yang lebih dari 2 minggu atau lebih yang dapat diikuti dengan keluhan batuk berdahak hingga berdarah, sesak nafas, badan lemas, nafsu makan menurun, berat badan menurun, malaise, berkeringat malam hari tanpa aktivitas fisik, dan demam disertai meriang lebih dari satu bulan (Nizar, 2010; Kemenkes RI, 2018).

Batuk merupakan kompensasi tubuh dalam mempertahankan paru terhadap rangssangan yang ada dan refleks fisiologis yang melindungi paru dari trauma mekanik, kimia, san suhu. Batuk merupakan gejala tersering untuk mengidentifikasi penyakit pada saluran pernapasan dan masalah yang sering kali dihadapi dalam praktik sehari-hari (Tameweol, dkk., 2016).

Batuk diperlukan untuk membuang produk-produk radang keluar. Karena terlibatnya bronkus pada setiap penyakit tidak sama, mungkin saja batuk baru ada setelah penyakit berkembang dalam 
jaringan paru yakni setelah berminggu-minggu atau berbulan-bulan peradangan bermula. Sifat batuk dimulai dari batuk kering kemudian setelah timbul peradangan menjadi produktif (menghasilkan sputum). Untuk mempermudah pengeluaran sputum dapat dipengaruhi beberapa faktor yaitu batuk efektif, postural drainase, vibrating dan clapping (Nugroho, 2011). Melakukan batuk yang benar bukan saja dapat mengeluarkan sputum secara maksimal tetapi juga dapat menghemat energi sehingga tidak mudah lelah dan dapat mengeluarkan dahak secara maksimal (Widiastuti \& Siagian, 2019).

Selain dengan batuk efektif, terdapat beberapa cara dalam pengendalian penyakit Tuberculosis paru yaitu dengan membudayakan hidup bersih dan sehat dan membudayakan perilaku etika berbatuk (Kemenkes RI, 2018). Etika berbatuk merupakan tata cara batuk yang benar dan efisien dengan caraa menutup hidung dan mulut dengan tissue atau lengan baju atau dengan menggunakan masker. Tujuan etika batuk untuk mencegaah perluasan penyebaran penyakit melalui udara (airbone) sehingga membuat kenyamanan orang terganggu atau menimbulkan suatu penyakit (Mastobing, 2018).

Dengan adanya permasalahan pada mitra, untuk itu perlu adanya pencegahan melalui penyuluhan dan demostrasi berupa batuk efektif, etika batuk dan pemberian masker dalam mencegah penyakit Tuberculosis pada masyarakat. Untuk mengetahui tingkat pengetahuan tingkat pengetahuan peserta maka dilakukan pre test dan post test. Pengetahuan masyarakat yang tepat tentang Tuberkulosis dan pencegahan melalui batuk efektif dan etika batuk dapat dijadikan sebagai strategi deteksi dini untuk dapat mempercepat tindakan pemeriksaan dan pengobatan sehingga dapat mencegah penularan Tuberkulosis akibat keterlambatan diagnosis.

\section{METODE}

Pengabdian masyarakat ini dilakukan selama 1 bulan (Maret-April 2020) dan berlokasi di RW. VI Kelurahan Sambikerep Surabaya. Pelaksanaan pengabidan masyarakat ini di bagi 3 tahap : 1) Pra kegiatan : rapat strategi pelaksanaan, survey lokasi, persiapan sarana dan prasarana. 2) Pelaksanaan kegiatan : pelaksanaan pengabdian masyarakat ini dengan cara penyuluhan dan demonstrasi yang dilakukan secara door to door dengan media leaflet, video tata cara batuk efektif dan etika batuk dan pembagian masker sehingga warga mampu melakukan secara mandiri dan mudah untuk diingat. Untuk mengetahui perubahan pengetahuan dan perilaku warga dilakukan pre-test dan post-test berupa kuesioner dan observasi langsung ke warga. 3) Pasca Kegiatan: dilakukan evaluasi yang dirancang untuk membandingkan kondisi pengetahuan dan kesadaran awal sebelum intervensi penyuluhan dan demosntrasi dengan peningkatan pengetahuan dan kesadaran setelah pelaksanaan penyuluhan dan demonstrasi.

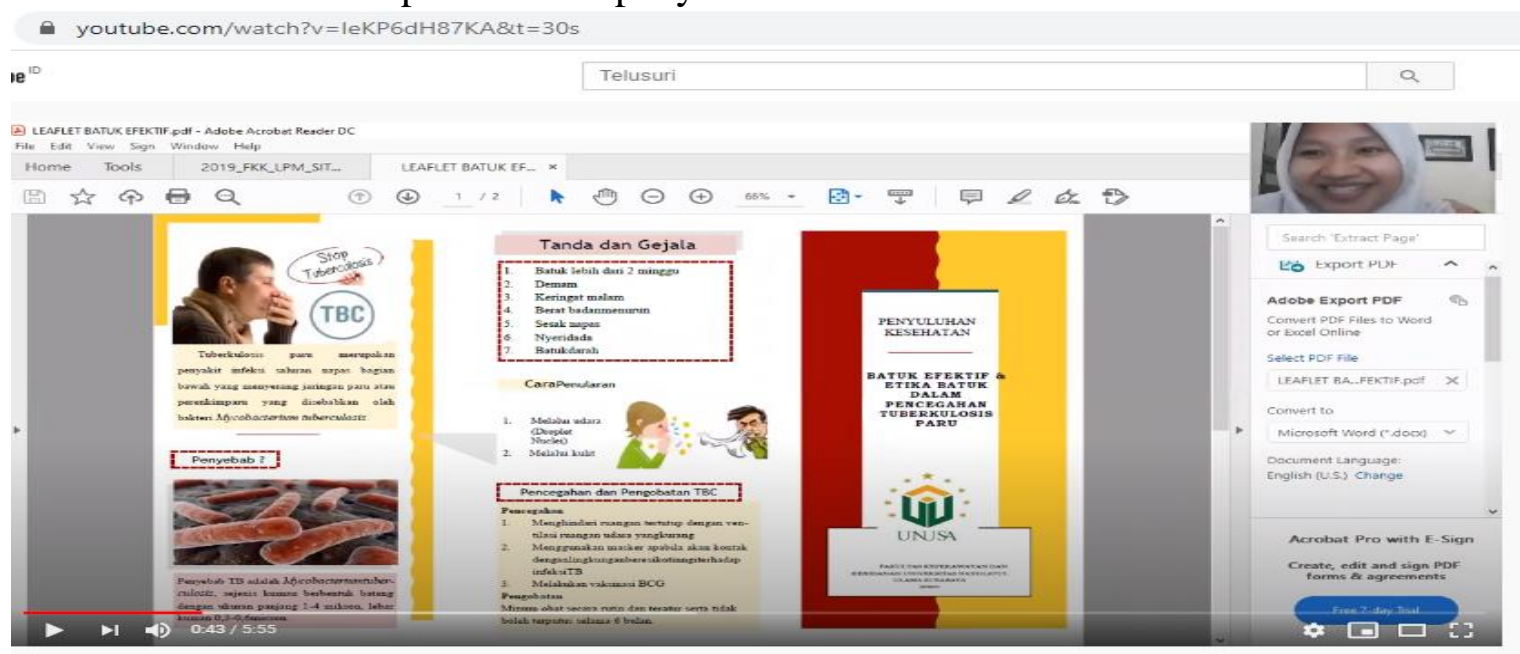

STOP TUBERKULOSIS PARU (TBC) DENGAN (BEEB) BATUK EFEKTIF DAN ETIKA BATUK

Gambar 1. Video Penyuluhan dan Demonstrasi Etika Batuk dan Batuk Efektif 


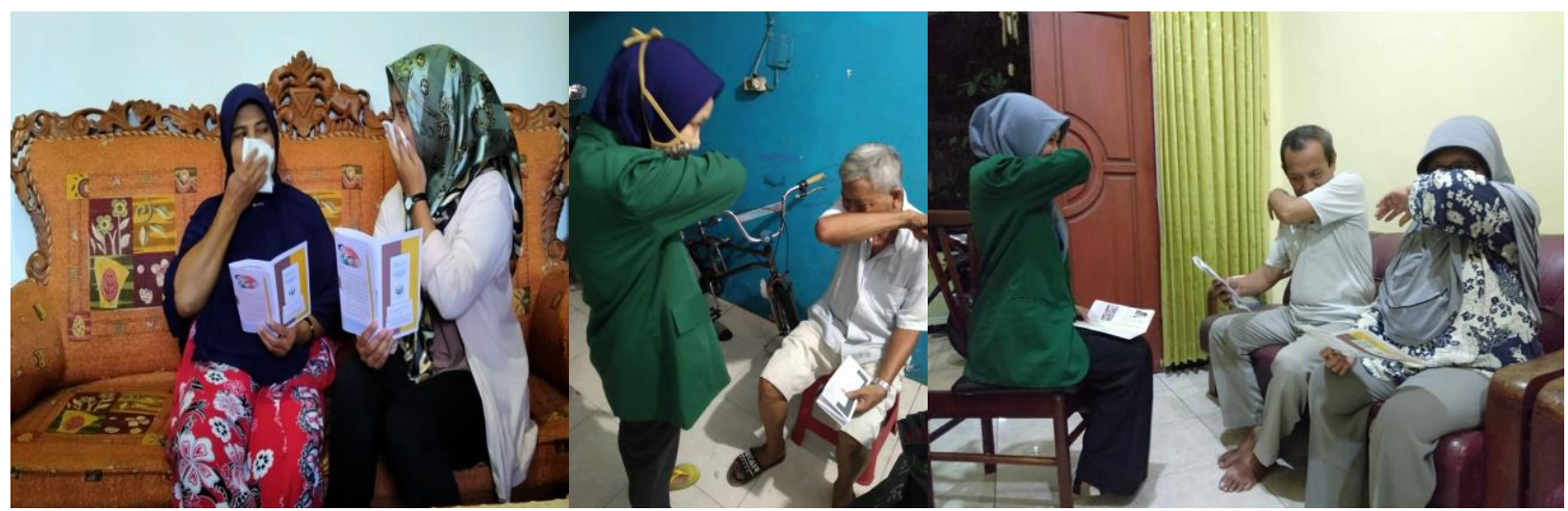

Gambar 2. Gambar Penyuluhan dan Demonstrasi

\section{HASIL DAN PEMBAHASAN}

Adapun hasil yang dicapai dari pelaksanaan kegiatan program pengabdian masyarakat berupa pencegahan penyebaran TBC paru dengan (BEEB) batuk efektif dan etika batuk di RW. VI Sambikerep Surabaya adalah sebagai berikut :

Tabel 1 Distribusi Responden Berdasarkan Usia

\begin{tabular}{cccc}
\hline No. & Usia & Jumlah & Presentase (\%) \\
\hline 1. & 25-34 tahun & 10 & 12,2 \\
2. & 35-44 tahun & 39 & 47,5 \\
3. & 45-54 tahun & 11 & 13,4 \\
4. & 55-65 tahun & 16 & 19,5 \\
5. & $>65$ tahun & 6 & 7,4 \\
\hline & Total & 82 & 100 \\
\hline
\end{tabular}

Berdasarkan Tabel 1 didapatkan hasil bahwa hampir setengahnya adalah usia 35-44 tahun yaitu sebesar 39 responden $(47,5 \%)$ dan sebagian kecil adalah usia $>65$ tahun yaitu sebesar 6 peserta $(7,4 \%)$.

Tabel 2 Distribusi Responden Berdasarkan Jenis Kelamin

\begin{tabular}{cccc}
\hline No. & Usia & Jumlah & Presentase (\%) \\
\hline 1. & Laki-Laki & 14 & 17 \\
2. & Perempuan & 68 & 83 \\
\hline & Total & 82 & 100 \\
\hline
\end{tabular}

Berdasarkan Tabel 2 didapatkan hasil bahwa hamper seluruhnya adalah perempuan yaitu sebesar 68 responden $(83 \%)$.

Tabel 3 Distribusi Responden Berdasarkan Tingkat Pengetahuan

\begin{tabular}{cccccccc}
\hline & \multicolumn{2}{c}{ Pre Test $(\mathrm{N}=82$ responden $)$} & \multicolumn{2}{c}{ Post Test $(\mathrm{N}=82$ responden $)$} \\
\hline \multicolumn{2}{c}{ Pengetahuan Baik } & \multicolumn{2}{c}{ Pengetahuan Kurang } & \multicolumn{3}{c}{ Pengetahuan Baik } & \multicolumn{2}{c}{ Pengetahuan Kurang } \\
\hline $\mathrm{n}$ & $\%$ & $\mathrm{~N}$ & $\%$ & $\mathrm{~N}$ & $\%$ & $\mathrm{~N}$ & $\%$ \\
\hline 3 & 3,7 & 79 & 96,3 & 74 & 90,2 & 8 & 9,8 \\
\hline
\end{tabular}

Berdasarkan tabel 3 diatas dapat dinyatakan bahwa hasil pre test responden berpengetahuan baik sebesar 3(3,7\%) dan setelah diberikan penyuluhan dan demonstrasi responden berpengetahuan baik menjadi 74(90,2\%). 
Kasus TB masih menjadi permasalahan serius di dunia. TB atau yang biasa disebut Tuberkulosis sering dikenal sebagai penyakit menular. Penyakit TB disebabkan oleh bakteri Mycobacterium Tuberculosis. TB dapat menyerang siapa saja tanpa memandang umur ataupun jenis kelamin, baik itu perempuan, laki-laki, dewasa maupun anak-anak. TB masih terus menjadi masalah kesehatan di dunia, terutama di negara berkembang termasuk Indonesia. Insiden TB yang terus meningkat menjadikan TB sebagai suatu penyakit yang disebut global health emergency (Wibowo, 2017).

Gejala yang paling dirasakan oleh penderita TBC adalah batuk. Batuk tidak lain adalah suatu refleks defensif belaka, untuk membersihkan saluran pernafasan dari sekret berupa mucus, bahan nekrotik, benda asing. Refleks ini bisa pula ditimbulkan oleh berbagai rangsangan pada mukosa saluran pernafasan (Danusantoso, 2016). Tertimbunnya sekret disaluran pernafasan bawah dapat menambah batuk semakin keras karena sekret menyumbat saluran nafas, sehingga cara lain untuk mengeluarkan sekret yang tertimbun tersebut dengan upaya batuk efektif. Latihan batuk efektif adalah aktivitas perawat untuk membersihkan sekresi pada jalan nafas, yang berfungsi untuk meningkatkan mobilisasi sekresi dan mencegah risiko tinggi retensi sekresi (Muttaqin, 2008).

Pencegahan penularan penyakit Tuberculosis dipengaruhi oleh perilaku penderita, keluarga dan masayarakat. Diketahui bahwa ada beberapa keadaan Tuberkulosis yang dapat meningkatkan resiko penularan yaitu penderita tidak menerapkan etika batuk dengan menutup mulut jika batuk atau bersin dan membung dahak tidak di tempat terbuka (Marissa \& Abidah, 2016). Serta perilaku buruk penderita Tuberkulosis dalam beretika batuk di karenakan pengetahuan masyarakat masih rendah dalam mengetahui pencegahan dan penularan tuberkulosis ( Sondak, dkk. 2016 ).

Kegiatan penyuluhan dan demonstrasi tentang pencegahan penyebaran TBC Paru dengan (BEEB) batuk efektif dan etika batuk dalam pengabdian masyarakat ini bermanfaat dalam meningkatkan pengetahuan masyarakat dan kesehatan masyarakat khususnya dalam mencegah penyebaran penyakit menular TBC Paru. Penyuluhan kesehatan ini didapatkan perubahan tingkat pengetahuan dan perilaku untuk hidup lebih sehat dan terhidar dari penyakit TBC Paru.

\section{SIMPULAN}

Kegiatan pengabdian dan masyarakat ini didapatkan peningkatan pengetahuan warga sebelum dilakukan kegiatan hasil pre test responden berpengetahuan baik sebesar 3(3,7\%) dan setelah diberikan penyuluhan dan demonstrasi responden berpengetahuan baik menjadi $74(90,2 \%)$. Kegiatan ini terlaksana dengan baik karena sumber daya manusia, kader-kader kesehatan RW. VI dan karang taruna yang membantu aktif dan sangat baik dalam menerima pembaruan untuk hidup sehat dan bersih agar terhindar dari penyakit menular khususnya Tuberkulosis paru.

Penyuluhan dan demonstrasi kesehatan ini didapatkan perubahan tingkat pengetahuan dan perilaku untuk hidup lebih sehat dan terhidar dari penyakit TBC Paru dengan cara (BEEB) Batuk efektif dan etika batuk yang dipantau selama 1 bulan pelaksanaan penyuluhan.

\section{SARAN}

Penyuluh berharap masyarakat dapat menerapkan batuk efektif dan etika batuk dalam mencegah penyebaran tuberkulosis paru secara mandiri dan dipertahankan untuk hidup lebih bersih dan sehat agar terhindar dari penyakit menular lainnya.

\section{UCAPAN TERIMA KASIH}

Penulis dan Tim mengucapkan terima kasih kepada para pihak terkait dalam melakukan pengabdian masyarakat ini terutama kepada Allah SWT, sivitas akademik Universitas Nahdlatul Ulama Surabaya, dan warga RW. VI Keluharan Sambikerep Surabaya.

\section{DAFTAR PUSTAKA}

Achmadi (2005) Hubungan antara Kualitas Fisik Rumah dan Kejadian Tuberkulosis Paru dengan Basil Tahan Asam positif di Balai Kesehatan Paru Masyarakat Semarang Jurnal Kedokteran Muhammadiyah, Volume 1, Nomor 1, Tahun 2005

Danusantoso, H. (2016). Tuberkulosis Paru. Dalam: Buku Saku Ilmu Penyakit Paru, Edisi 2.Jakarta: EGC 
Dinkes Jatim, 2016. Sebanyak 207.667 Pasien TB di Jatim Berhasil Disembuhkan.,pp.1-2, Diakses tanggal 10 Oktober 2020, http://kominfo.jatimprov.go.id/read/umum/sebanyak207-667-pasien-tb-

Fatimah, S. (2008). Faktor Kesehatan Lingkungan Rumah Yang Berhubungan Dengan Kejadian Tb Paru Di Kabupaten Cilacap (Kecamatan : Sidareja, Cipari, Kedungreja, Patimuan, Gandrungmangu, Bantarsari) Tahun 2008, Tesis. Semarang.: Universitas Diponegoro

Kementerian Kesehatan RI. (2018). Pusat data dan Informasi Kementerian Kesehatan RI : Tuberkulosis. Jakarta: Kementerian Kesehatan RI Pusat data dan Informasi ISNN 24427659

Marissa, Nelly., Nur, Abidah. (2014). Gambaran Infeksi Mycobacterium Tuberculosis Pada Anggota Rumah Tangga Pasien Tb Paru (Studi Kasus di Wilayah Kerja Puskesmas Darul Imarah Kabupaten Aceh Besar). Media Litbangkes, Vol. 24 No. 2, 89 - 94.

Mastobing, "Penerapan Etika Batuk Dalam Mencegah Penyebaran Bakteri Tuberkulosis Pada Pasien Tb Paru Diruang Rawat Inap Anggrek (Isolasi) RS Dr. Sobirin Kabupaten Musi Rawas

,"Repository Poltekkes Kemenkes Palembang, accessed June 4, 2020, https://repository.poltekkespalembang.ac.id/items/show/612.

Mumpuni Y, Lestari W. 2016. Cekal (Cegah\&Tangkal) SampaiTuntas TBC. Yogyakarta :Andi

Muttaqin, Arif. (2008). Buku Ajar Asuhan Keperawatan Klien dengan Gangguan Sistem Pernapasan. Jakarta: Salemba Medika.

Nizar, M. 2010. Pemberantasan dan Penanggulangan Tuberkulosis. Yogyakarta: Gosyen Publishing

Nugroho, Agung Yosef. (2011). Batuk Efektif dalam Pengeluaran Dahak Pada Pasien Dengan Ketidakefektifan Bersihan Jalan Nafas di Instalasi Rehabilitasi Medik Rumah Sakit Baptis Kediri. http://puslit2.petra.ac.id/ejournal/index.php/stikes/article/view/18621

Nurdiana, dkk. (2018). Pengaruh Kondisi Fisik Rumah Terhadap Penularan TB paru pada Anggota Keluarga (Studi Kasus di Wilayah Kerja Puskesmas Perak Timur Surabaya Tahun 2018). Surabaya:

http://journal.poltekkesdepkessby.ac.id/index.php/KESLING/article/download/824/626

Sondak, Maykel., Porotu'o, John., Homenta, Heriyannis. (2016). Hasil Diagnostik Mycobacterium Tuberculosis Dari Sputum Penderita Batuk $\geq 2$ Minggun Dengan Pewarnaan Ziehl Neelsen Di Puskesmas Paniki Bawah, Tikala Baru Dan Wonasa Manado. Jurnal eBiomedik (eBm), Vol 4, No 1.

Tamaweol, D., Ali, R.H., Simanjuntak, M.L. 2016. Gambaran Foto Toraks Pada Penderita Batuk Kronis di Bagian/SMF Radiologi FK Unsrat/RSUP Prof. Dr. R. D. Kandou Manado. Jurnal e-Clinic (eCl).Vol. 4, No.1

Widiastuti, L. \& Siagian, Y. (2019). Pengaruh Batuk Efektif Terhadap Pengeluaran Sputum Pada Pasien Tuberkulosis di Puskesmas Kampung Bugis Tanjung Pinang. Jurnal Keperawatan, 9. Jurnal stikeshangtuah-tpi.ac.id

World Health Organization. (2015). Tuberculosis: WHO Global Tuberculosis Report. Fathsheet: World Health Organization.

WHO. (2017). Global Tuberculosis Report 2017. Jenewa

Wibowo. Ahmad Eko. (2017). Hubungan karakteristik Perawat Dengan Perilaku Pencegahan Dan Pengendalian Infeksi TB (PPI TB) Di RS Paru Jember, Skripsi. Surabaya: Universitas Airlangga 